\title{
Influence of temperature and nitrogen on growth, photosynthesis and accumulation of non-structural carbohydrate in a tropical grass, Panicum maximum var. trichoglume
}

\author{
J. R. Wilson
}

Institute for Biological and Chemical Research on Field Crops and Herbage (IBS), Wageningen, the Netherlands ${ }^{1}$

Accepted: 20 November 1974

\section{Summary}

The effects of change in growth temperature and nitrogen status on factors influencing the accumulation of non-structural carbohydrates in a tropical grass, Panicum maximum var, trichoglume, were investigated.

Plants were grown on half-strength Hoagland's solution at $25^{\circ} \mathrm{C}$ in a controlled environment room. After an initial growth period, one-half the number of plants were transferred to 'nil' $\mathrm{N}$ nutrient solution. Plants from both $\mathrm{N}$ treatments were exposed to temperatures of $15,20,25,30$ and $35^{\circ} \mathrm{C}$ (constant day and night). Treatment effects were analysed in terms of whole plant relative growth rate $\left(R_{W}\right)$, relative leaf area growth rate $\left(R_{A}\right)$, net assimilation rate per unit leaf area $\left(E_{A}\right)$, and percentage of total non-structural carbohydrates (\% TNC) in the tops and roots. On similarly treated plants, measurements were also made of net photosynthetic rate $\left(\mathrm{P}_{N}\right)$ and dark respiration rate of attached leaves.

Leaf $P_{N}, R_{W}$ and $E_{A}$ were affected to a similar relative extent with change in temperature or nitrogen status, thereby precluding the accumulation of very high levels of \% TNC in any treatment. However, the utilization of assimilates for new productive plant structure, viz $\mathbf{R}_{A}$, was relatively more retarded by low temperature (high $\mathrm{N}$ plants) and low nitrogen level (all temperatures) than was assimilatory input. Some changes in \% TNC were thus recorded, which were inversely associated with the trends in $\mathbf{R}_{\mathrm{A}}$ and also to a degree with change in dark respiration rate. For the high $\mathrm{N}$ plants, it is believed that the reduction in \% TNC at the higher temperatures was accentuated by the use of constant day/night temperature regimes. The temperature influence on the \% TNC in low $\mathrm{N}$ plants was minor.

1 Present address: C.S.I.R.O., Division of Tropical Agronomy, Cunningham Laboratory, Mill Road, St. Lucia, Queensland, Australia. 


\section{Introduction}

Non-structural carbohydrates in grasses are a readily utilizable energy source for grazing animals and their level of accumulation is considered important to the overall quality of herbage (Alberda, 1965). Also, in forage species, non-structural carbohydrates are of interest in relation to regrowth potential after defoliation (Alberda, 1966) and probably also to winter survival of plants.

Tropical pasture grasses in general appear to accumulate lower levels of nonstructural carbohydrates than do the commonly used species of temperate grasses (Wilson \& Ford, 1971, 1973). Also, in contrast to the response of temperate $\left(C_{3}\right)$ species, accumulation of non-structural carbohydrates in tropical $\left(C_{4}\right)$ grasses appears to be relatively little affected by nitrogen supply (Wilson, 1975), or change of temperature within reasonable limits of the regimes these grasses would normally be expected to experience (McKell et al., 1969; Balasko \& Smith, 1971; Deinum \& Dirven, 1972; Wilson \& Ford, 1971, 1973). Although, under unusual growing conditions, high starch levels were reported in Digitaria exposed to $10^{\circ} \mathrm{C}$ night temperatures after summer day conditions of high irradiance and temperature (Hilliard \& West, 1970).

The almost invariable accumulation of high concentrations of non-structural carbohydrates in temperate grasses under declining temperature and nitrogen status (e.g. Alberda, 1965; Smith, 1973) has by implication been attributed to these factors reducing the formation of new tissue relatively more than photosynthetic rate (Blaser et al., 1966). By analogy, a comparable hypothesis to explain the relative stability of non-structural carbohydrate levels in tropical grasses is that both growth and photosynthetic rate are affected to a similar degree by change in temperature or nitrogen status.

This hypothesis is investigated with a tropical $\left(C_{4}\right)$ grass, Panicum maximum var. trichoglume grown over a range of temperatures at high and low levels of nitrogen. The relative effects of treatment on plant growth parameters and leaf photosynthetic characteristics are assessed and compared with the accumulation of non-structural carbohydrates in the plant.

\section{Methods}

Two experiments with $P$. maximum var. trichoglume were conducted in controlled environment rooms at the Institute for Biological and Chemical Research on Field Crops and Herbage (IBS), Wageningen, Netherlands. Comparison was made between plants of high and low $\mathrm{N}$ status grown under different temperature regimes (with constant day and night conditions) of 25 and $35^{\circ} \mathrm{C}$ in Exp. 1 ; and 15, 20, 25 and $30^{\circ} \mathrm{C}$ in Exp. 2.

\section{Plant culture and growth analysis}

Seed was germinated on sand at $25^{\circ} \mathrm{C}$ and at the 3-leaf stage seedlings were selected for uniformity and transferred to 1-litre pots containing half-strength Hoagland's nutrient solution (one plant/pot). Iron was added as $1 \mathrm{ml}$ of $0.3 \mathrm{M}$ solution 
of ferrous sulphate in $1 \mathrm{~N}$ sulphuric acid. Initially, solutions were renewed at weekly intervals but the frequency was progressively increased as the plants grew larger.

The pots were arranged in a randomized block design on trolleys in controlled environment rooms set to a 17-hour daylength of illumination from banks of 400 W high-pressure mercury vapour lamps giving $70 \mathrm{~J} \mathrm{~m}^{-2} \mathrm{~s}^{-1}$ of photosynthetically active radiation $(400-700 \mathrm{~nm})$ at plant height. Relative humidity during the day was $65-75 \%$ and at night $85-90 \%$ in each temperature treatment.

All plants were grown at a constant $25^{\circ} \mathrm{C}$ day and night until day 31 from sowing (Exp. 1) or day 37 (Exp. 2). At this stage the plants each had 6-7 tillers, the longer growth period in Exp. 2 arising from a delay in germination. Harvests 1 and 2 were taken on days 28 and 31 (Exp. 1), and 34 and 37 (Exp. 2).

The plants were then allocated to their specific temperature treatments and harvests 3 and 4 made at three-day intervals, viz days 34 and 37 (Exp. 1), and days 40 and 43 (Exp. 2).

Plants of low nitrogen status were obtained by substituting a 'nil' $\mathrm{N}$ nutrient solution for the half-strength Hoagland's solution subsequent to day 30 or 36 in the two experiments, respectively. In the 'nil' $\mathrm{N}$ solution, $\mathrm{K}_{2} \mathrm{SO}_{4}$ replaced $\mathrm{KNO}_{3}$, and $\mathrm{CaCl}_{2} \cdot 6 \mathrm{H}_{2} \mathrm{O}$ replaced $\mathrm{Ca}\left(\mathrm{NO}_{3}\right)_{2} \cdot 4 \mathrm{H}_{2} \mathrm{O}$, to maintain the original balance of cations.

Sufficient plants were grown in each treatment for separate use in the analysis of growth, leaf photosynthetic rate, and diurnal trends in total non-structural carbohydrates. Blocks, and plants within blocks, were re-randomized thrice weekly.

For growth analysis, six replicate plants were harvested per treatment, the harvests commenced one hour after the start of the photoperiod and were completed within about one hour. Plants were separated into laminae, stems (including sheaths), and roots, which were weighed after oven-drying at $70{ }^{\circ} \mathrm{C}$ for 24 hours. The dried samples were ground to pass a $1-\mathrm{mm}$ sieve and used for estimation of total non-structural carbohydrates. Total leaf area per plant (excluding dead leaves) was measured with an electronic planimeter. Weight and area data were transformed to logarithms for analysis of variance.

\section{Leaf photosynthesis}

Net photosynthesis $\left(\mathrm{P}_{\mathrm{N}}\right)$ and dark respiration rates of attached leaves were measured with the assembly described by Louwerse \& van Oorschot (1969), with simultaneous recording from four separate leaf chambers. The measurements were made at the same temperature as that at which the plants in each specific temperature treatment were grown. Replicate measurements were obtained with two chambers per treatment. Three plants were allocated to a chamber and from each plant the last, fully expanded leaf on two main tillers was used, i.e. each leaf chamber contained six attached leaves. Dark respiration rate was determined and then $P_{N}$ was measured over a range of light intensities. Subsequently, area, fresh and dry weight, and nitrogen content of the leaf material exposed in each chamber was determined. Measurements in Exp. 1 were made on the day equivalent to days 34 (25 and $35^{\circ} \mathrm{C}$ high $\mathrm{N}$ plants) and $35\left(25\right.$ and $35^{\circ} \mathrm{C}$ low $\mathrm{N}$ plants $)$ of the growth trial. In 


\section{INFLUENCE OF TEMPERATURE AND NITROGEN ON PANICUM MAXIMUM}

Exp. 2, the corresponding days were day 40 (15 and $25^{\circ} \mathrm{C}$ high $\mathrm{N}$ ), 41 (20 and $30^{\circ} \mathrm{C}$ high and low $\left.\mathrm{N}\right)$ and $42\left(15\right.$ and $25^{\circ} \mathrm{C}$ low $\left.\mathrm{N}\right)$.

\section{Chemical analysis}

Organic-nitrogen and nitrate-nitrogen were estimated for the leaves used in the photosynthesis tests using the procedures described by Alberda (1965).

Total non-structural carbohydrates (TNC) were determined on top and root samples from the growth trial plants as the sum of sugars and starch soluble in warm water. Starch was solubilized by boiling the sample under reflux for 1 hour and was then hydrolysed by pancreatine ( $\mathrm{pH} \mathrm{6)}$ during 24 hours at $38^{\circ} \mathrm{C}$. The extract was deproteinized with zinc ferricyanide. Reducing power in both warmwater and starch extracts was measured after acid hydrolysis by the method of Shaeffer \& Somogyi (1933).

The diurnal trend of \% TNC in tops of plants high in nitrogen only was determined for the 24 hours immediately after transfer of plants to the specific temperatures. Plants were harvested for analysis at $08 \mathrm{~h} 00,12 \mathrm{~h} 00,16 \mathrm{~h} 30$ and $21 \mathrm{~h} 00$ (end of photoperiod), and again at 08 h00 (start of next photoperiod). Chemical data are expressed as a percentage of dry weight.

\section{Basis of comparison}

The relative effects of treatment on growth parameters, $\mathrm{P}_{\mathrm{N}}$, respiration and \% TNC are compared by expressing data for individual temperature $\times$ nitrogen treatment combinations on the basis of their percentage of the corresponding value for the $25^{\circ} \mathrm{C}$ high $\mathrm{N}$ treatment (Fig. 4, Table 3) in each experiment, respectively.

Whole plant relative growth rate $\left(R_{W}=g^{-1}\right.$ day-1), relative leaf area growth rate $\left(R_{A}=\mathrm{cm}^{2} \mathrm{~cm}^{-2}\right.$ day-1), and net assimilation rate per unit leaf area $\left(E_{A}=\right.$ $\mathrm{g} \mathrm{cm}^{-2}$ day $^{-1}$ ) were derived for each treatment, for the day corresponding to that on which $\mathbf{P}_{\mathrm{N}}$ was measured, by interpolation on the appropriate growth curves for $\log _{10}$ dry weight and leaf area. The growth parameters were calculated according to Williams (1946). Similarly, \% TNC values corresponding to the day of photosynthesis test for each treatment were obtained by interpolation, using the data in Fig. 3.

The appropriate $P_{N}$ values were obtained from the light response curves for the level of photosynthetically active radiation equivalent to that at which the plants were grown in the controlled environment rooms, viz $70 \mathrm{~J} \mathrm{~m}^{-*} \mathrm{~s}^{-1}$.

\section{Results}

\section{Growth response}

The plants were vegetative and growing actively in both experiments with the $R_{W}$ of the $25^{\circ} \mathrm{C}$ high $\mathrm{N}$ plants being in the range of 0.27 to $0.19 \mathrm{~g} \mathrm{~g}^{-1}$ day $^{-1}$ over the first two harvest intervals. Data for the $25^{\circ} \mathrm{C}$ treatment were very similar in both experiments in relation to plant size (Table 1), $P_{N}$ (Fig. 1), and leaf $N$ content (Table 2). Hence comparisons for the $35^{\circ} \mathrm{C}$ treatment in Exp. 1 are on a basis comparable to that for the other temperatures in Exp. 2. 
J. R. WILSON

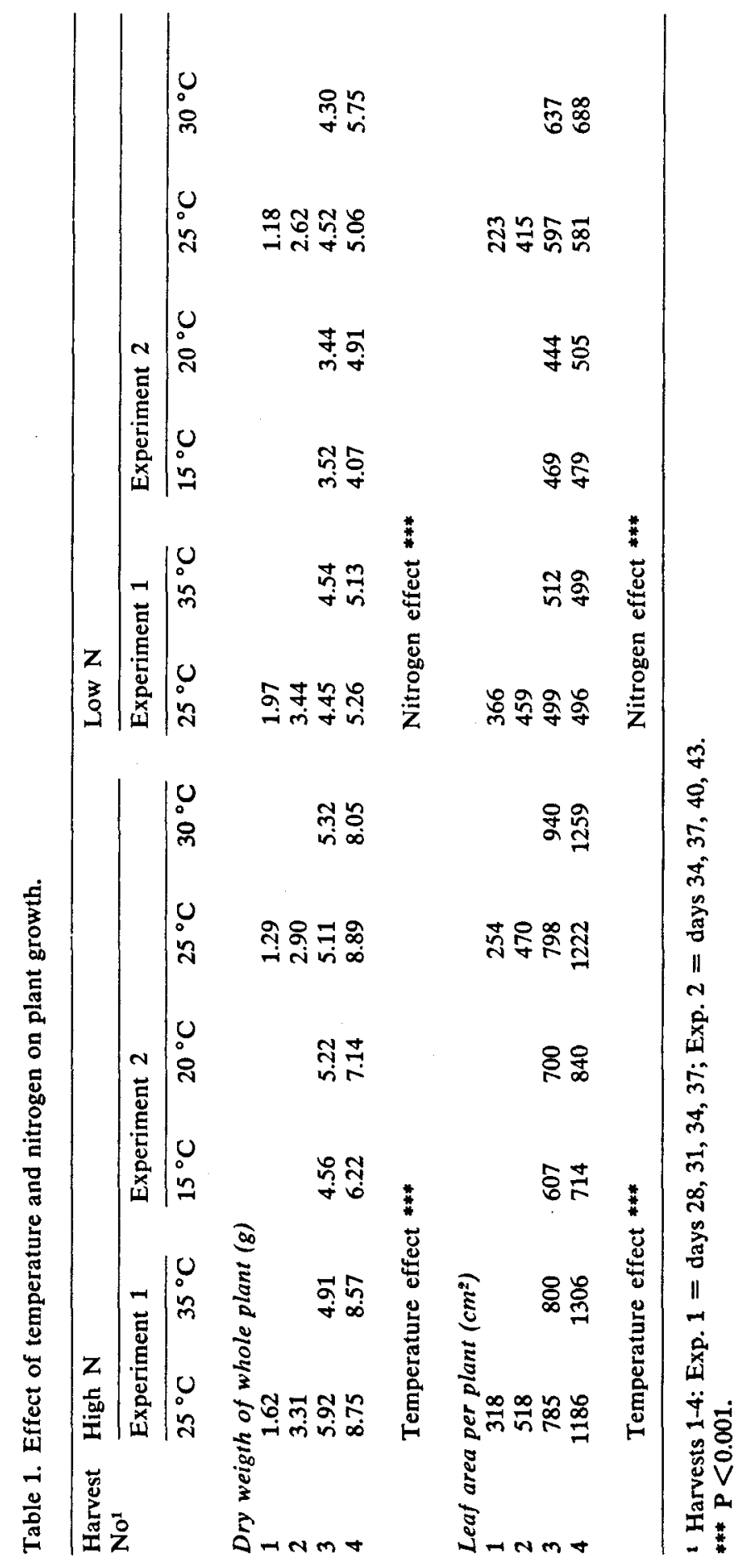



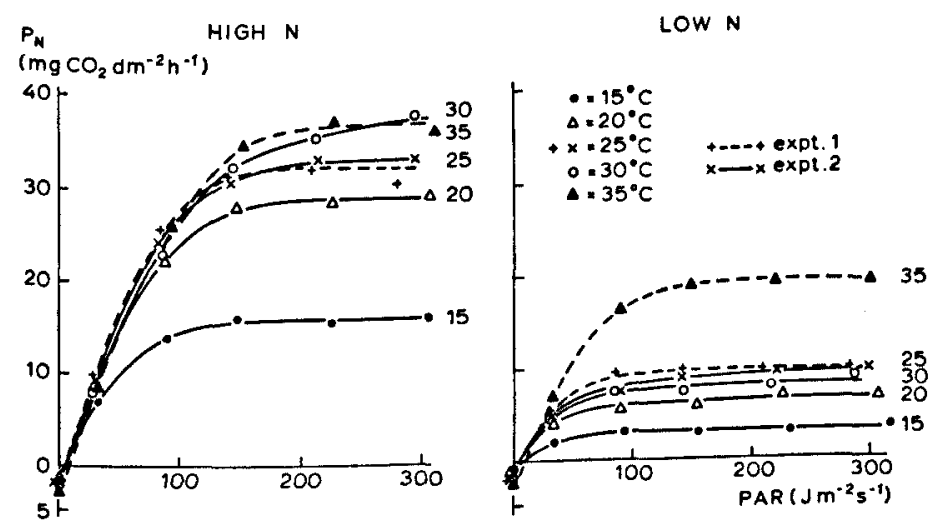

Fig. 1. Influence of temperature and nitrogen on the net photosynthesis $\left(P_{N}\right)$-photosynthetically active radiation (PAR) response curves of leaves of Panicum maximum var. trichoglume.

Growth in dry weight and leaf area (Table 1$)$ was decreased $(P<0.001)$ by both low temperature and low $\mathrm{N}$ status. At harvest 3 the low $\mathrm{N}$ plants were noticeably paler in colour and the degree of $\mathrm{N}$ deficiency was such as to markedly restrict further increase in leaf area. Dry weight yield still showed a small but consistent increase between harvests 3 and 4 .

\section{Leaf photosynthesis $\left(P_{N}\right)$}

The $P_{N}$-light response curves presented in Fig. 1 indicate in general form a clear tendency towards light saturation at the higher levels of irradiation in all treatments. The $P_{N}$ was decreased by temperatures of 15 and $20^{\circ} \mathrm{C}$ in both high and low $\mathrm{N}$ plants, but was rather similar for temperatures in the range of $25-35^{\circ} \mathrm{C}$. Temperature effects were more pronounced at the higher levels of irradiation in the leaf chamber. The value for $35^{\circ} \mathrm{C}$ low $\mathrm{N}$ plants appears anomalously high; there is no obvious explanation for this and the high value is not supported by the equivalent $\mathrm{E}_{\mathrm{A}}$ from the growth analysis plants. The leaf area data (Table 1) indicate that the $35^{\circ} \mathrm{C}$ low $\mathrm{N}$ plants were $\mathrm{N}$-deficient, although the $\mathrm{N}$ content of the leaves tested for photosynthesis (Table 2) was slightly higher than that of 25 and $30^{\circ} \mathrm{C}$

Table 2. Nitrogen content $(\%)$ of leaves used for measurement of photosynthetic rate. ${ }^{1}$

\begin{tabular}{|c|c|c|c|c|c|c|}
\hline \multirow{2}{*}{$\begin{array}{l}\text { Nitrogen } \\
\text { treatment }\end{array}$} & \multicolumn{2}{|c|}{ Experiment 1} & \multicolumn{4}{|c|}{ Experiment 2} \\
\hline & $25^{\circ} \mathrm{C}$ & $35^{\circ} \mathrm{C}$ & $15^{\circ} \mathrm{C}$ & $20^{\circ} \mathrm{C}$ & $25^{\circ} \mathrm{C}$ & $30^{\circ} \mathrm{C}$ \\
\hline High & 3.39 & 3.38 & $\begin{array}{l}3.66 \\
1.82\end{array}$ & $\begin{array}{l}2.90 \\
1.46\end{array}$ & $\begin{array}{l}3.37 \\
1.40\end{array}$ & $\begin{array}{l}3.02 \\
1.46\end{array}$ \\
\hline
\end{tabular}

${ }^{1} \mathrm{NO}_{3}-\mathrm{N}$ in range $0.07-0.28 \%$.

Neth. J. agric. Sci. 23 (1975) 


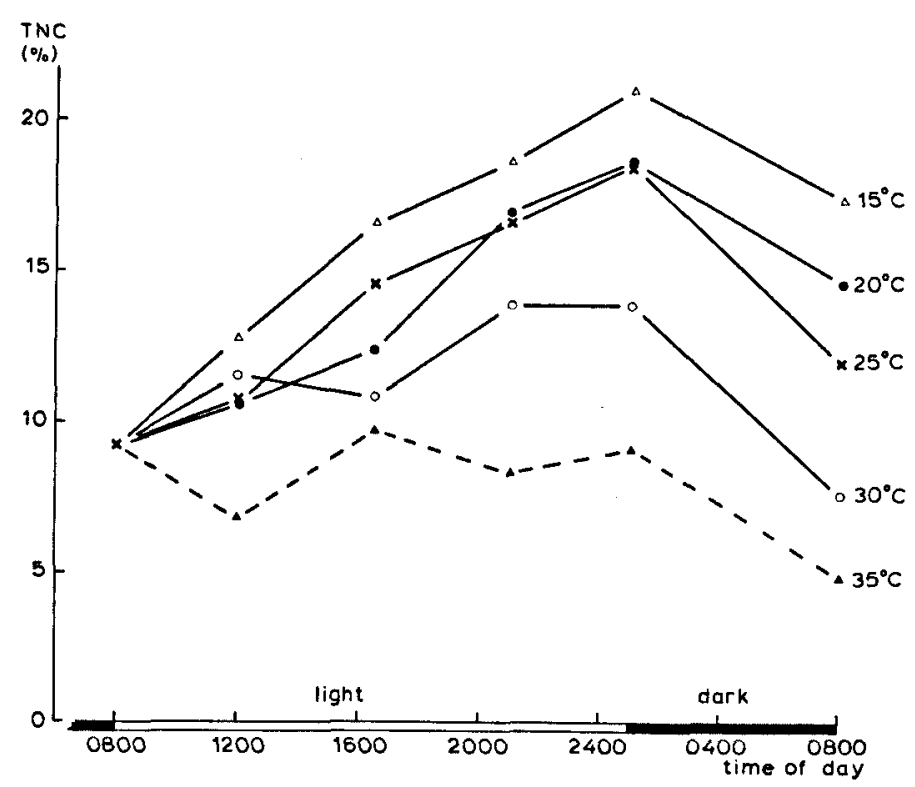

Fig. 2. Change in \% TNC in tops of high $\mathrm{N}$ plants during the first 24 hours of temperature treatment. Data for $35^{\circ} \mathrm{C}$ is from Exp. 1. L.S.D. $(P=0.05)$ : temperature, $1.9 \%$; times, $1.6 \%$.

treatments. With the above exception, $\mathrm{P}_{\mathrm{N}}$ was severely restricted in the low $\mathrm{N}$ plants, the effect being similar at all levels of irradiation.

Dark respiration was reduced in the low $\mathrm{N}$ plants, but in both $\mathrm{N}$ treatments the rate increased with increasing temperature. These treatment effects are more clearly seen in Fig. 4.

\section{Total non-structural carbohydrates (TNC)}

The changes in \% TNC of tops in high $\mathrm{N}$ plants during the first 24 hours after transfer from $25^{\circ} \mathrm{C}$ to their treatment temperatures (Fig. 2), indicate a clear diurnal trend at all temperatures with a progressive increase in \% TNC during the photoperiod $(\mathrm{P}<0.001)$ and a decline at night. After 24 hours the \% TNC at $25^{\circ} \mathrm{C}$ was approximately equal to that at the start, whereas at 15 and $20^{\circ} \mathrm{C}$ $\%$ TNC values were substantially higher and at 30 and $35^{\circ} \mathrm{C}$ they tended to be lower.

These trends were reflected at harvest 3 of the growth trial plants, with \% TNC significantly $(\mathrm{P}<0.001)$ decreasing with increasing growth temperature (Fig. 3 ). But at harvest 4 after six days treatment the tendency towards convergence of the data suggests some adaptation to the temperature treatments. The low $\mathrm{N}$ plants in general had higher \% TNC than the high $\mathrm{N}$ plants $(\mathrm{P}<0.001)$. There was, however, a significant $(P<0.001)$ interaction with temperature, the difference between $\mathrm{N}$ treatments being very small at $15^{\circ} \mathrm{C}$ and increasing to $6-7$ percentage units at 30 and $35^{\circ} \mathrm{C}$. 

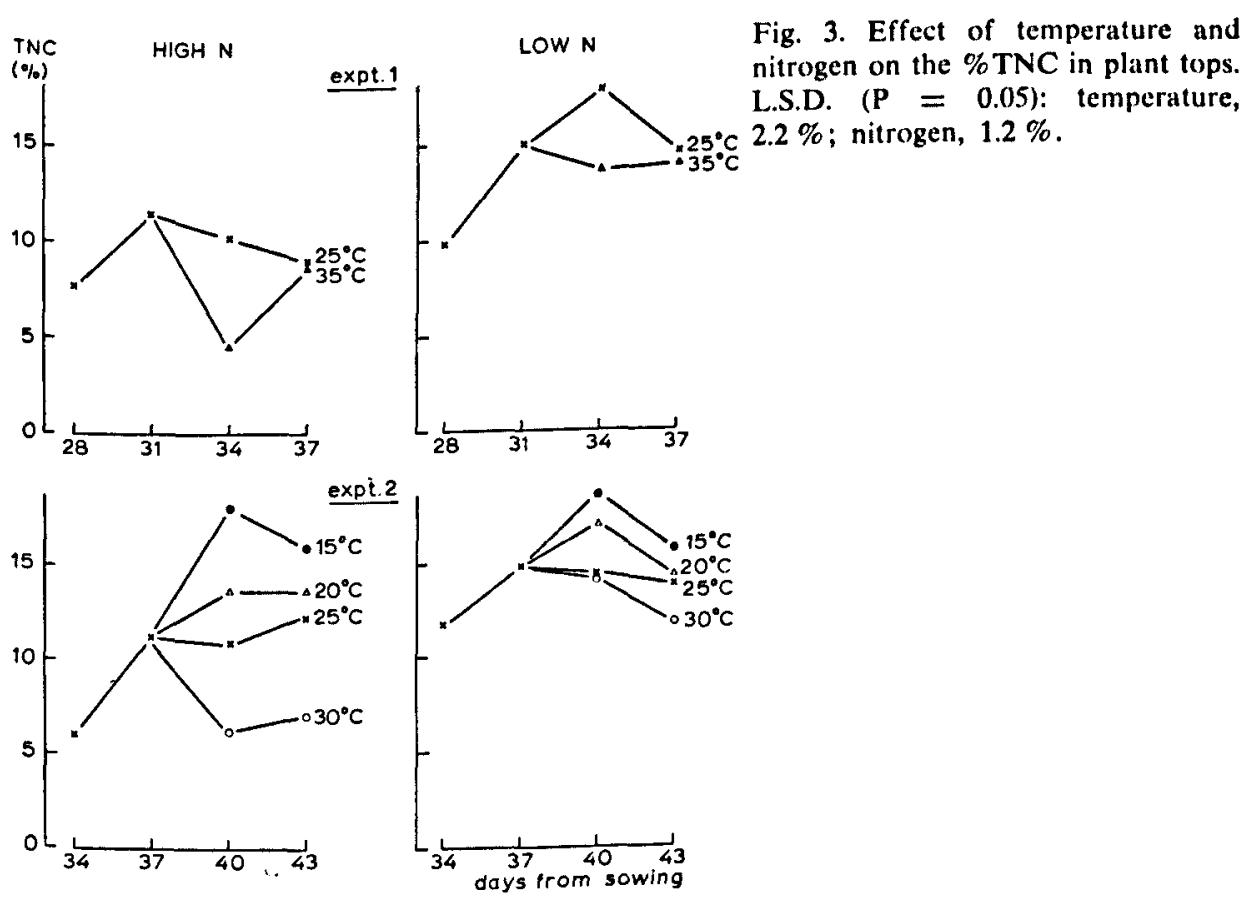

Harvest effects on \% TNC of roots were non-significant, and values averaged over harvests 3 and 4 for 15 to $30^{\circ} \mathrm{C}$, respectively, were for low $\mathrm{N}$ plants $6.1,7.5,5.9$, $6.3 \%$ and for high $\mathrm{N}$ plants $8.5,8.8,8.9,7.2 \%(\mathrm{P}<0.05-1.1 \%)$. The \% TNC was generally lower than for tops and there was no consistent trend with temperature. The higher \% TNC in the high compared with low $N$ plants $(P<0.001)$ is directly opposite to the data for plant tops.

\section{Comparative response of different parameters}

Fig. 4 presents the relative effects of temperature and $\mathrm{N}$ on growth, $\mathrm{P}_{\mathrm{N}}$ and respiration, and corresponding data for \% TNC are given in Table 3 .

Both $R_{W}$ and $P_{N}$ of high $N$ plants were similarly affected by temperature and this remained true for low $N$ plants although the rates of activity were substantially reduced (Fig. 4a). Dark respiration rates of low $\mathrm{N}$ leaves were consistently lower than those of high $\mathrm{N}$ leaves but the relative reduction in rate due to $\mathrm{N}$ deficiency was much less than for $R_{W}$ or $P_{N}$. The rate declined with decrease in temperature in approximately linear form down to $20^{\circ} \mathrm{C}$ for leaves of both high and low $\mathrm{N}$ status, with a $\mathrm{Q}_{10}$ of $c .1 .65$ and 1.85 for the $\mathrm{N}$ treatments, respectively. The rates for $15^{\circ} \mathrm{C}$, particularly the high $\mathrm{N}$ treatment, seem unexpectedly high.

Further analysis of the growth response (Fig. 4b) in terms of $E_{\Lambda}$ (net assimilation of carbon) and $R_{\Lambda}$ (utilization of carbon in new productive potential) revealed a wider divergence of treatment effect. In the high $\mathrm{N}$ treatment, $\mathrm{R}_{\mathrm{A}}$ showed a more 

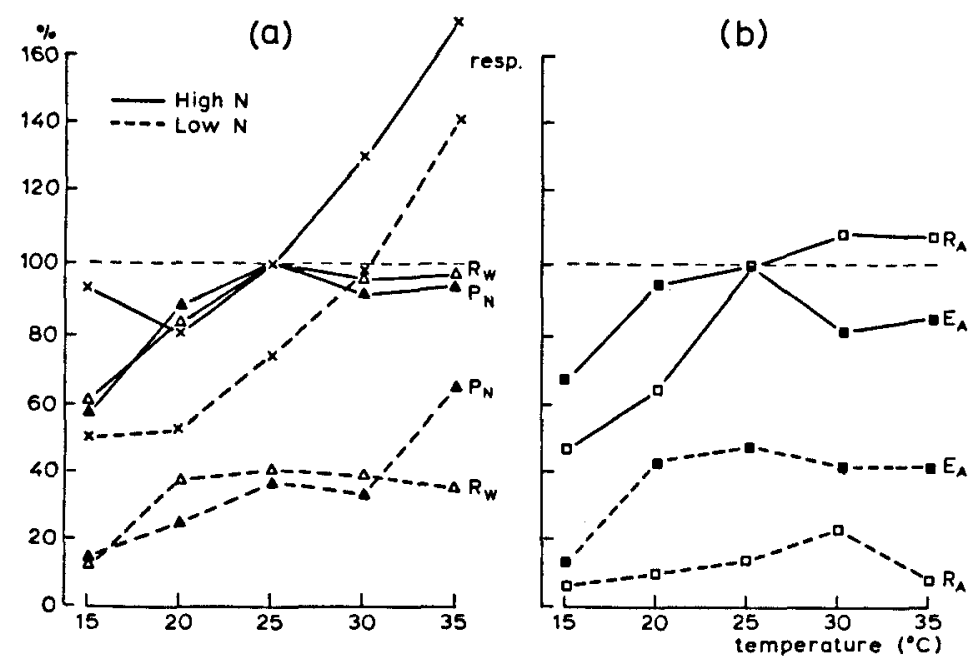

Fig. 4. Comparative effect of treatment on (a) relative growth rate of whole plant $\left(R_{W}\right)$, leaf net photosynthesis $\left(P_{N}\right)$, and leaf dark respiration (resp.); (b) relative leaf area growth rate $\left(R_{A}\right)$, and net assimilation rate per unit leaf area $\left(E_{A}\right)$ (data expressed relative to the value for the $25^{\circ} \mathrm{C}$ high $\mathrm{N}$ treatment).

pronounced response to temperature than did $\mathrm{E}_{\mathrm{A}}$, being promoted at high temperatures and retarded at low temperatures. In plants of low $\mathrm{N}$ status temperature effects were damped but low $N$ restricted $R_{A}$ much more than $E_{A}$.

The relative effects of treatment on these parameters are reflected in the corresponding data for \% TNC in the plant tops (Table 3), for example in the high $\mathrm{N}$ plants, TNC accumulated at low temperatures and depleted at high temperatures. Temperature had less effect on \% TNC in tops of low N plants, but with the exception of the $15^{\circ} \mathrm{C}$ treatment the overall level of accumulation was higher than

Table 3. Influence of temperature and nitrogen on the relative accumulation of total nonstructural carbohydrate (\% TNC, values estimated for the day of the photosynthesis test, expressed as a percentage of the $25^{\circ} \mathrm{C}$ high $\mathrm{N}$ value).

\begin{tabular}{llllll}
\hline $\begin{array}{l}\text { Temperature } \\
\left({ }^{\circ} \mathrm{C}\right)\end{array}$ & Tops & & \multicolumn{2}{c}{ Roots } \\
\cline { 2 - 3 } \cline { 5 - 6 } & high N & low N & & high N & low N \\
15 & 165 & 144 & & 105 & 76 \\
20 & 120 & 142 & & 96 & 85 \\
25 & 100 & 126 & & 100 & 77 \\
30 & 57 & 119 & & 87 & 82 \\
35 & 45 & 132 & & 53 & 96 \\
\hline
\end{tabular}


that of high $\mathrm{N}$ plants. The root data revealed no consistent effect of temperature and the overall $\mathrm{N}$ effect on \% TNC was opposite to that of the tops.

\section{Discussion}

The interrelation of the growth parameters in this study provide some insight into the factors influencing the accumulation of TNC in a tropical grass. Plant growth rate and leaf photosynthetic rate were similarly affected by change in temperature and nitrogen level. These data for $P$. maximum thus suggest little opportunity for very high levels of \% TNC to accumulate under limiting growth conditions.

However, the \% TNC values obtained for tops of high $\mathrm{N}$ plants indicate an effect of temperature on accumulation which is somewhat larger in range than expected from previous experience (Wilson \& Ford, 1973). The reason for this is not evident from consideration of $R_{W}$ which is perhaps a somewhat insensitive index of the productive usage of fixed carbon, because change in dry weight may include the accumulation of carbohydrate reserves. The consumption of assimilate for growth to provide new productive potential is better measured in the short term by $R_{\Lambda}$, particularly as consumption for root growth would be relatively minor with top to root dry weight ratios as high as $6-9$. In the current study, $R_{\Lambda}$ was obviously more sensitively affected by treatment than $\mathbf{R}_{W}$.

The trends in \% TNC in response to temperature and nitrogen were inversely associated with $\mathrm{R}_{A}$, and also to an extent with dark respiration. However, taking dark respiration into account did not greatly modify treatment effects on assimilatory input as seen by comparing the trends in $E_{A}$ with those for $P_{N}$ of individual leaves (Fig. 4). In the low $\mathrm{N}$ plants, despite a large relative change in respiration rate with temperature, the temperature influence on TNC accumulation was very small, and the overall increase in TNC level was largely associated with the substantial decline in $R_{A}$ evident at all temperatures. Respiration not directly related to growth, viz maintenance respiration, is estimated at about $1.5 \%$ of dry matter per day (Penning de Vries, 1972) which does not represent a large loss of reserve carbohydrate. The importance of leaf growth rate as a factor controlling \% TNC level was clearly demonstrated for Digitaria by Chatterton et al. (1972) in that actively tillering plants did not accumulate starch when given a cool night, but if plants were pre-treated so that tillering was stopped then accumulation occurred. Also, the abnormal accumulation of starch reported by Wilson \& Ford (1971) for Setaria and Panicum grown at high temperature is now known to be associated with a temporary physiological syndrome of restricted and deformed expansion of new leaves which appears in tropical grasses under good growing conditions when maximum night humidities remain below c. $85 \% \mathrm{RH}$.

The somewhat steeper than expected change in \% TNC of tops in the high $N$ plants with change in growth temperature is believed to be largely associated with the high temperature end of the treatment range. Whereas, levels of accumulation at 15 and $20^{\circ} \mathrm{C}$ were similar to those recorded by Wilson \& Ford (1971, 1973) for tropical grasses grown at comparably low temperatures. Compared to other growing conditions with a day/night temperature differential, the constant 
temperature conditions as employed in the current work greatly increase, at 30 and $35^{\circ} \mathrm{C}$, the night respiratory load. Some of the extra respiratory load may represent unproductive consumption of carbohydrate, but in the main it probably contributed towards, and indeed would be necessary for, the synthetic processes associated with the higher rate of leaf area expansion. An additional stimulus to leaf expansion from higher night temperature may derive from faster translocation of accumulated assimilates from the leaves as shown for $P$. maximum by Lush \& Evans (1974). Through these effects the decline in \% TNC was probably accentuated to a degree unlikely to be experienced under field growing conditions.

Another possible factor exacerbating the low TNC level at the higher temperatures is the low relative photosynthetic and net assimilation rate shown by the $P$. maximum plants at 30 and $35^{\circ} \mathrm{C}$. This may result from the relatively low irradiation levels under which the plants were grown in the controlled environment rooms, which according to Treharne et al. (1971) would restrict $P_{N}$ more at the high than at the low temperatures. The maximum $P_{N}$ values recorded for $P$. maximum in this trial were similar to those obtained by Ludlow \& Wilson (1971b) for the same species grown at $33 \%$ of full daylight. In other studies of tropical grasses (Murata \& Iyama, 1963; Ludlow \& Wilson, 1971a), $P_{N}$ has shown both a steeper increase with temperature and a higher temperature optimum than was recorded for $P$. maximum in this experiment.

However, whether a higher level of irradiation would have definitely enhanced the level of TNC accumulation at the high temperatures is difficult to assess because both respiration rate (Ludlow \& Wilson, 1971b) and $\mathbf{R}_{W}$ (Ludlow et al., 1974) also increase under high illumination. The \% TNC in tropical grasses grown under high irradiation in the field (Jones, 1966; Catchpoole, 1968; Hunter et al., 1970; Deinum \& Dirven, 1972; Dovrat et al., 1972) is generally lower than recorded under lower irradiation in controlled environment (Wilson \& Ford, 1971, 1973). A similar observation was made for temperate grasses by Alberda (1970). The low incident radiation in controlled environment studies is compensated to a considerable extent by better distribution of illumination to all leaves in spaced, individually grown plants. In the current trial, additional compensation was derived from the 17-hour photoperiod compared to maximum daylengths of 13-14 hours experienced under tropical field conditions. Furthermore, in swards, despite high irradiation, light may be limiting during much of the day (Brown et al., 1966) and in this respect it is interesting that the marked photosynthetic advantage of tropical over temperate grasses reported for single leaves is much reduced at canopy photosynthesis level (Gifford, 1974).

The very high values of \% TNC, up to $25-40 \%$ of dry weight, accumulated in temperate grasses under declining temperature or low $\mathrm{N}$ status (e.g. Alberda, 1965; Wilson \& Ford, 1973) clearly suggest that there is a greater disparity in the response of carbohydrate assimilation in relation to usage in temperate than in tropical grasses. Direct evidence to support this contention in relation to the effect of nitrogen is given by Wilson (1975). With respect to temperature, a similar inference may perhaps be drawn indirectly from indications for temperate grasses that the optimum temperature for $\mathrm{P}_{\mathrm{N}}$, c. $15^{\circ} \mathrm{C}$ (Murata \& Iyama, 1963), is ap- 
parently lower than for growth, 20-25 ${ }^{\circ} \mathrm{C}$ (Mitchell, 1956; Davidson \& Milthorpe, 1965). Also, dark respiration rate of temperate grasses shows a proportionately greater reduction with decline in temperature than does photosynthetic rate (Murata \& Iyama, 1963).

By comparison with tropical grasses, temperate or $\mathrm{C}_{3}$ species show a slower and less complete translocation of assimilates from their leaves (Hofstra \& Nelson, 1969; Lush \& Evans, 1974), and may tend to distribute a lower proportion of fixed carbon into new productive potential, viz by maintaining a lower top/root ratio (Wilson \& Haydock, 1971). The extent to which factors such as these contribute to the relative differences in TNC accumulation between tropical and temperate grasses warrants assessment.

A further moderating influence on reserve carbohydrate accumulation in tropical grasses, particularly under field conditions, is that they are frequently low in $\% \mathrm{~N}$ content as discussed by Wilson \& Haydock (1971). The present data clearly indicate that this would considerably reduce any tendency towards \% TNC accumulation at lower temperatures. Especially would this be so for tropical grass herbage in late autumn when $\% \mathrm{~N}$ content is normally very low. In contrast, for temperate grasses the influence of low temperature and low nitrogen in enhancing $\%$ TNC level would be complementary.

Finally, whilst the present approach allows a semi-quantitative appreciation of factors influencing accumulation of TNC, a longer-term objective should be the integration of such data in simulation models permitting prediction of changes in TNC for a wide range of growth conditions.

\section{Acknowledgments}

I wish to thank Dr E. M. Hutton, Chief, C.S.I.R.O., Division of Tropical Agronomy, Brisbane, Australia, and Dr Th. Alberda, Deputy Director, I.B.S., Wageningen, Netherlands, for their co-operation in providing the opportunity and facilities for this research. I also wish to thank Dr Alberda for his helpful advice during this work. I extend my appreciation to Mrs Janny Witlage and Miss Margreet Geurtsen for their help with the experiments, and to the staff of the I.B.S. for the chemical analyses and photosynthesis measurements.

\section{References}

Alberda, Th., 1965. The influence of temperature, light intensity and nitrate concentration on dry-matter production and chemical composition of Lolium perenne L. Neth. J. agric. Sci. 13: $335-360$.

Alberda, Th., 1966. The influence of reserve substances on dry matter production after defoliation. Proc. 10th int. Grassland Congr. (Helsinki): 140-147.

Alberda, Th., 1970. The influence of carbohydrate reserves on respiration, photosynthesis and dry matter production of intact plants. Proc. $11 \mathrm{~h} \mathrm{~h}$ int. Grassland Congr. (Surfer's Paradise): 517-522.

Balasko, J. A. \& D. Smith, 1971. Influence of temperature and nitrogen fertilization on the growth and composition of Switchgrass (Panicum virgatum L.) and Timothy (Phleum pratense L.) at anthesis. Agron. J. 63: 853-857. 
Blaser, R. E., R. H. Brown \& H. T. Bryant, 1966. The relationship between carbohydrate accumulation and growth of grass under different microclimates. Proc. 10th int. Grassland Congr. (Helsinki): 147-150.

Brown, R. H., R. E. Blaser \& H. L. Dunton, 1966. Leaf-area index and apparent photosynthesis under various microclimates for different pasture species. Proc. 10th int. Grassland Congr. (Helsinki): 108-113.

Catchpoole, V.R., 1968. Effect of season, maturity and rate of nitrogen fertilizer on ensilage of Setaria sphacelata. Aust. J. exp. Agric. Anim. Husb. 8: 569-573.

Chatterton, N. J., G. E. Carlson, W. E. Hungerford \& D. R. Lee, 1972. Effects of tillering and cool nights on photosynthesis and chloroplast starch in pangola. Crop Sci. 12: 206-208.

Davidson, J. L. \& F. L. Milthorpe, 1965. The effect of temperature on the growth of cocksfoot (Dactylis glomerata L.). Ann. Bot. (N.S.) 29: 407-417.

Deinum, B. \& J. G. P. Dirven, 1972. Climate, nitrogen and grass. 5. Influence of age, light intensity and temperature on the production and chemical composition of Congo grass (Brachiaria ruziziensis Germain et Everard). Neth. J. agric. Sci. 20: 125-132.

Dovrat, A., B. Deinum \& J. G. P. Dirven, 1972. The influence of defoliation and nitrogen on the regrowth of Rhodes grass (Chloris gayana Kunth). 2. Etiolated growth and non-structural carbohydrate, total $-\mathrm{N}$ and nitrate $-\mathrm{N}$ content. Neth. J. agric. Sci. 20: 97-103.

Gifford, R. M., 1974. A comparison of potential photosynthesis, productivity and yield of plant species with differing photosynthetic metabolism. Aust. J. Pl. Physiol. 1: 107-117.

Hilliard, J. H. \& S. H. West, 1970. Starch accumulation associated with growth reduction at low temperatures in a tropical plant. Science N. Y. 168: 494-496.

Hofstra, G. \& C. D. Nelson, 1969. A comparative study of translocation of assimilated ${ }^{14} \mathrm{C}$ from leaves of different species. Planta 88: 103-112.

Hunter, R. A., B. L. McIntyre \& R. J. McIlroy, 1970. Water-soluble carbohydrates of tropical pasture grasses and legumes. J. Sci. Fd Agric. 21: 400-405.

Jones, R. J., 1966. The effect of urea-mollasses supplements on the winter performance of beef cattle on improved pastures at Samford, southeastern Queensland. Aust. J. exp. Agric. Anim. Husb. 6: 145-149.

Louwerse, W. \& J. L. P. van Oorschot, 1969. An assembly for routine measurements of photosynthesis, respiration and transpiration of intact plants under controlled conditions. Photosynthetica 3: 305-315.

Ludlow, M. M. \& G. L. Wilson, 1971a. Photosynthesis of tropical pasture plants. I. Illuminance, carbon dioxide concentration, leaf temperature and leaf-air vapour pressure difference. Aust. J. biol. Sci. 24: 449-470.

Ludlow, M. M. \& G. L. Wilson, 1971b. Photosynthesis of tropical pasture plants. II. Temperature and illuminance history. Aust. J. biol. Sci. 24: 1065-1075.

Ludlow, M. M., G. L. Wilson \& M. R. Heslehurst, 1974. Studies on the productivity of tropical pasture plants. V. Effect of shading on growth, photosynthesis and respiration in two grasses and two legumes. Aust. J. agric. Res. 25: 425-433.

Lush, W. M. \& L. T. Evans, 1974. Translocation of photosynthetic assimilate from grass leaves as influenced by environment and species. Aust. J. Pl. Physiol. 1: 417-431.

McKell, C. M., V. B. Youngner, F. J. Nudge \& N. J. Chatterton, 1969. Carbohydrate accumulation of Coastal Bermuda grass and Kentucky bluegrass in relation to temperature regimes. Crop. Sci. 9; 534-537.

Mitchell, K. J., 1956. Growth of pasture species under controlled environment I. Growth at various levels of constant temperature. N.Z. Jl Sci. Tech. A. 38: 203-216.

Murata, Y. \& J. Iyama, 1963. Studies on the photosynthesis of forage crops. II. Influence of air temperature upon the photosynthesis of some forage and grain crops. Proc. Crop. Sci. Soc. Japan. 31: 315-322.

Penning de Vries, F. W. T., 1972. Respiration and growth. In: A. R. Rees et al. (Ed.), Crop processes in controlled environments, Academic Press, London, p. 327-346.

Shaeffer, P. A. \& M. Somogyi, 1933. Copper - iodometric reagents for sugar determination. J. biol. Chem. 100: 695-713. 


\section{INFLUENCE OF TEMPERATURE AND NITROGEN ON PANICUM MAXIMUM}

Smith, D., 1973. The non-structural carbohydrates. In: G. W. Butler \& R. W. Bailey (Ed.), Chemistry and biochemistry of herbage. Academic Press, London. Vol. 1: 106-155.

Treharne, K. J., A. J. Pritchard, and J. P. Cooper, 1971. Variation in photosynthesis and enzyme activity in Cenchrus ciliaris L. J. exp. Bot. 22: 227-238.

Williams, R. F., 1946. The physiology of plant growth with special reference to the concept of net assimilation rate, Ann. Bot. (N.S.) 10: 41-72.

Wilson, J. R., 1975. Comparative response to nitrogen deficiency of a tropical and temperate grass in the interrelation between photosynthesis, growth, and the accumulation of nonstructural carbohydrate. Neth. J. agric. Sci. 23 (in press.)

Wilson, J. R. \& C. W. Ford, 1971. Temperature influences on the growth, digestibility and carbohydrate composition of two tropical grasses, Panicum maximum var. trichoglume and Setaria sphacelata, and two cultivars of the temperate grass Lolium perenne. Aust. J. agric. Res. 22: 563-571.

Wilson, J. R. \& C. W. Ford, 1973. Temperature influences on the in vitro digestibility and soluble carbohydrate accumulation of tropical and temperate grasses. Aust. J. agric. Res. 24: 187-198.

Wilson, J. R. \& K. P. Haydock, 1971. The comparative response of tropical and temperate grasses to varying levels of nitrogen and phosphorus nutrition. Aust. J. agric. Res. 22: 573-587. 